\title{
A fotografia na experiência educativa de professores: do olhar e das interpretações
}

\section{The photograph on the educational experience of teachers: look and interpretations}

\author{
Daniele Marques Vieira*
}

\begin{abstract}
RESUMO
Este texto desenvolve um método para pensar a educação como experiência educativa (CONTRERAS; PÉREZ, 2010) com uso da fotografia. Tal elaboração se dá no campo da Pedagogia, sob uma perspectiva inspirada na filosofia (BENJAMIN, 1986; 2012; GADAMER, 2013; ARENDT, 2013), com referentes da fotografia pela dimensão estética (BARTHES, 1980; DUBOIS, 1998; VÁZQUEZ, 2005). Tem como objetivo discutir o constructo teórico de um método que utiliza a fotografia para pensar a experiência educativa de professores. Desenvolve a ideia do sujeito que observa a imagem como receptor e elemento determinante à sua compreensão, situado temporal e espacialmente no decurso do processo histórico, identifica algo no horizonte do vivido observado com o que pode estabelecer diálogo. Apresenta a fotografia como instrumento à análise interpretativa da realidade pelo encontro de horizontes, entendida enquanto objeto da cultura que expressa uma visão sobre a realidade e se constitui em aparato de observação pela possibilidade de gerar interpretações decorrentes daquilo que afeta o sujeito receptor da imagem. Ao interpretar o que vê na fotografia como indícios da prática educativa, o observador aciona sua experiência educativa e realiza o exercício de pensar sobre o vivido e evidenciado na imagem. Destaca-se que a fotografia não constitui mera representação dos referentes que evidencia, mas, enreda mundos em relação, de uma perspectiva histórica e estética.
\end{abstract}

Palavras-chave: Fotografia. Experiência Educativa. Professores.

* Universidade Federal do Paraná. Curitiba, Paraná, Brasil. E-mail: danielemarquesvieira@ gmail.com. https://orcid.org/0000-0001-6866-7053 


\begin{abstract}
This text develops a method to think of education as an educational experience (CONTRERAS; PÉREZ, 2010) with the use of photography. This elaboration takes place in the field of Pedagogy from a perspective inspired by philosophy (BENJAMIN, 1986, 2012, GADAMER, 2013, ARENDT, 2013) with references to photography by the aesthetic of dimension. It aims at discussing the theoretical construct of a method that uses photography to think about the educational experience of teachers. It develops the idea of the subject who observes the image as a receptor and determinant element to its comprehension, situated temporally and spatially in the course of the historical process, identifying something in the horizon of lived observed with what can establish dialogue. It presents photography as an instrument to the interpretative analysis of reality through the encounter of horizons, understood as an object of culture that expresses a vision about reality and constitutes an apparatus of observation for the possibility of generating interpretations arising from what affects the subject receiving the image. In interpreting what they see in the photograph as evidence of educational practice, the observer activates their educational experience and carries out the exercise of thinking about what is lived and evidenced in the image. It is emphasized that photography is not merely a representation of the referents that are in evidence, but it entangles worlds in relation from a historical and aesthetic perspective.
\end{abstract}

Keywords: Photography. Educational Experience. Teachers.

\title{
Pensar a educação como experiência educativa com a fotografia
}

\author{
A pesquisa educacional não está centrada \\ em dar conta de uma realidade, \\ em explicá-la, \\ senão em perguntar-se pelo sentido educativo \\ que pode abrir-se em uma experiência \\ que tratamos de entender. \\ Contreras e Pérez (2010)
}

Sobre o que constitui a experiência educativa, parto da compreensão de que o "saber é algo dinâmico, nunca resolvido, que apenas 'é', que somente existe, na medida em que é vivido nas mentes de quem o elaboram ou de quem o recriam e o atualizam, e que the dão sentido ao receber ou trabalhar com ele" (CONTRERAS; PÉREZ, 2010, p. 49). 
Há, portanto, uma renovação implicada no saber da experiência pelo ato de pensar, pois "o que caracteriza a experiência e o seu saber é precisamente sua abertura ao novo, ao inesperado, o reconhecimento de que não podemos confiar em um saber acumulado" (CONTRERAS; PÉREZ, 2010, p. 49). Mas, porque se sabe o que se vive em determinado contexto educativo, reconhecer o vivido é o que permite interpretar o sentido da experiência, não como algo a devir, senão como concretude encarnada das relações que o sustentam, cuja representação fotográfica possibilita voltar-se e rememorar.

Frente a isso, apresento um método de pesquisa que se filia no campo da Pedagogia, em uma perspectiva inspirada na filosofia (BENJAMIN, 1986; 2012; GADAMER, 2013; ARENDT, 2013) e que utiliza a fotografia com base na dimensão da estética (BARTHES, 1980; DUBOIS, 1994; VÁZQUEZ, 2005). Com o objetivo de discutir o constructo teórico do referido método, este texto desenvolve a ideia do sujeito que observa a imagem como receptor e elemento determinante à sua compreensão, situado temporal e espacialmente no decurso do processo histórico; identifica algo no horizonte do vivido observado com o que pode estabelecer diálogo; e interpreta a fotografia pelo ato de pensar os elementos que a compõem, por sua evidência e composição, como reflexão da própria experiência educativa.

Toda experiência sempre nos remete a um momento vivido, permeado de sentimentos, sensações e percepções, marcado por realizações e desacertos de algo que passou em um tempo remoto ou recente, indubitavelmente, do que já foi. Deste modo, a reflexão sobre a experiência a partir da fotografia se situa em um presente que se volta ao passado, cujo espaço educativo para onde o sujeito se remete, sob os efeitos desses tempos em relação, reluz pela evidência de elementos com os quais ele interage e demarca suas referências do vivido. Dessas relações resultam significados construídos e materializados por interpretações visibilizadas pela imagem.

A representação fotográfica, por vezes calcada no intento de reproduzir o real, constitui ato criativo, na medida em que a imagem produzida se compõe de elementos correspondentes a uma realidade eleita em relação ao imaginário do seu produtor. Deste modo, se faz necessário conhecer aspectos que concernem à origem da fotografia (SONTAG, 1981; BENJAMIN, 1986; KOSSOY, 1989; FELICI, 2011; MARTINS, 2013) quanto ao seu modo de representação e as relações que subsistem em sua função como objeto da cultura a ser apropriado pelo receptor da imagem.

Para referenciar a análise imagética, apresento a descrição de uma fotografia por Walter Benjamin (2013) como possibilidade à reflexão desta enquanto constructo verossímil, dada sua natureza mecânica de captura do real, mediante os significados que emergem de relações derivadas da experiência do ensaísta 
e crítico pelo que os elementos da imagem lhe dão a pensar. E por fim, discuto o constructo teórico desse método como possibilidade para pensar a fotografia na experiência educativa de professores.

\section{A imagem e a construção de realidades: das referências do olhar e suas múltiplas interpretações}

Estudos sobre a estética da recepção com foco na obra de arte (VÁZQUEZ, 2005) contribuíram a pensar o caso da fotografia, desde a relação entre a recepção da imagem e sua interpretação à constituição do olhar que escolhe e a acolhe, seja em sua captura ou observação, sendo entendida a fotografia como também uma obra criativa.

Ao aludir à práxis artística em Da estética da recepção a uma estética da participação ${ }^{1}$, Vázquez (2005) destaca que toda doutrina estética se baseia na tríade produtor, produto e receptor da obra de arte. No entanto, ressalva que no decurso da história do pensamento estético essa tríade se apresenta sob uma relação desigual em que predomina ora a atenção no produtor, ora no produto, cujo receptor parece resignado à passividade da contemplação. Esse pensamento passivo do receptor teria suas origens na Modernidade que concebia a obra de arte sob uma autonomia absoluta com um fim em si mesma, enquanto contraposição à concepção de arte como meio ou instrumento, cuja finalidade no período pré-moderno era, sobretudo, servir à religião ou à política. "Esta concepção da recepção contemplativa e do papel passivo do receptor dela somente será questionada - ao menos frontalmente - no terreno teórico na década dos 60 do século XX" (VÁZQUEZ, 2005, p. 16).

Dentre os precursores que enlevaram o papel do receptor da imagem, Walter Benjamin se destaca por sua abordagem à crítica de arte que, diante da obra relativiza a atualização de sua recepção, no sentido de que "não enfatiza a recepção como um encontro atual com a obra, senão o caráter histórico da sua recepção" (VÁZQUEZ, 2005, p. 18). Com isso, o autor sugere a ênfase ao receptor como elemento determinante da análise, pois enquanto sujeito que

1 Segundo Vázquez (2005) a Estética da Recepção, fundada por Robert Hans Jauss e Wolfgang Iser na Universidade de Colônia em 1967 se baseou em antecedentes teóricos que contribuíram para a sua estruturação. No caso da problematização do papel do receptor na obra de arte, se encontram estudos de Platão e Aristóteles, Paul Valéry, Walter Benjamin e Jean Paul Sartre, e acerca da recepção como marco de uma teoria geral se situam os pensadores Roman Ingarden, Jan Mukarovsky e Hans Georg Gadamer. 
vive em um tempo e em um espaço, está imerso nas decorrências do processo histórico que marcam a obra artística, da sua produção à sua observação e sob a influência da sujeição do que a própria história deixou chegar ao presente e assinalou como relevante. Nessa perspectiva, a observação e a análise de uma obra de arte ocorrem sob a recepção do que os olhos do presente veem, mediados por outros olhares que também lhe atribuíram significados ao longo do seu percurso histórico enquanto constructo artístico. E, ainda que o receptor da obra compreenda o contexto em que ela surgiu, não há uma interpretação determinada, nem mesmo resignada ao seu criador, senão, possibilidades interpretativas que sempre a ressignificam, uma vez que se constitui objeto da cultura, permeável às apropriações dos sujeitos em seu tempo.

Aliada à ideia de compreensão da obra de arte como interpretação da realidade, marcada pelo encontro de horizontes, a hermenêutica de Gadamer (apud VÁZQUEZ, 2005; 2013) busca um elemento comum nesse encontro, o que possibilitaria o diálogo entre a obra enquanto acontecimento e o presente de quem a observa. Vale destacar a ideia de horizonte como algo que se matiza em inúmeras versões, ou pontos de vistas sobre o mesmo acontecimento ocorrendo concomitantemente, ou seja, percepções ou interpretações do mesmo fato, que constituem testemunho deste em uma perspectiva histórica.

Seguindo esse pensar filosófico, me volto a Hannah Arendt (2013) ao abordar a experiência como um construto, cujo pensamento vinculado ao acontecimento engloba uma situação em dado momento do processo vivenciado pelo sujeito. Para essa autora, o pensamento enquanto reflexão se situa em um entre que resulta de uma colisão de forças, de um lado a tradição do passado como herança transmitida pelas velhas gerações e de outro lado as possibilidades vislumbradas no futuro como perspectivas de transformação do mundo. Dessa colisão se produz um rompimento no continuum do tempo, um vazio, em que o pensamento, arraigado em um inevitável presente, e sob direção determinada do choque entre passado e futuro, emerge como força diagonal lançada ao infinito (ARENDT, 2013), o que se convencionou chamar de lacuna arendtiana.

A imagem de lacuna, proposta por Arendt (2013), configura esse vazio ou espaço virtual, situado apenas no âmbito dos fenômenos mentais e refere o pensamento como atividade atemporal, ao qual o sujeito do presente se vincula por um tempo e um espaço, enquanto marcos de orientação, pelo exercício do ato de pensar. Desse modo, nesse espaço intemporal, o pensamento se caracteriza como insurgência e pode ser indiciado pelas coordenadas que o orientam: "a cada nova geração, e na verdade cada novo ser humano, inserindo-se entre um passado infinito e um futuro infinito, deve descobri-lo e, laboriosamente, pavimentá-lo de novo" (ARENDT, 2013, p. 40). 
Se considerarmos que o pensamento se move nesse espaço intemporal da lacuna arendtiana, o exercício de pensar a educação como experiência pela fotografia, sugere uma aproximação do passado que ela refere à própria experiência calcada no vivido, ressignificado pelo presente, que emerge como pensamento. Em acordo com a perspectiva gadameriana, seria como se a imagem acionasse o seu receptor pelo reconhecimento de algo comum. Com isso, podemos perguntar: seria possível a fotografia constituir um instrumento à análise interpretativa da realidade pelo encontro de horizontes?

Tal indagação enseja ao exercício reflexivo sobre verossimilhança e imaginário que a fotografia detém, os quais se evidenciam nesta descrição de Walter Benjamin² sobre uma imagem de Kafka criança.

Raramente "a pobre e breve infância" terá sido capturada em uma imagem tão comovedora como em certa fotografia de Kafka criança. Vem de um desses estúdios do século XIX que, com suas cortinas e palmeiras, suas tapeçarias e cavaletes, teriam alguma coisa de câmara de tortura e de sala do trono ao mesmo tempo. Com seu apertado e humilhante traje infantil carregado de adornos, nela se representa uma criança de apenas seis anos em meio a uma espécie de paisagem de estufa. Leques de palmeiras se erguem ao fundo. E, como se valesse a pena fazer ainda mais pegajosos $\mathrm{e}$ opressivos estes trópicos acolchoados, o modelo sustenta na mão esquerda um chapéu desproporcional de abas largas, como dos espanhóis. Olhos incomensuravelmente tristes dominam a paisagem que lhe está destinada e na qual uma concha de uma grande orelha está à escuta. $\mathrm{O}$ ardente desejo de "converter-se em um pele vermelha" poderia ter devorado esta grande tristeza: "E se ele fosse um índio, sempre alerta, montado em um cavalo a galope, inclinado contra o vento, tremendo em intervalos cada vez mais curtos no terreno trepidante, até abandonar as esporas que já não havia, até lançar ao ar as rédeas que não tinha, até apenas ver a paisagem à frente como um pântano cortado rente". (BENJAMIN, 2013, p. 59).

Depreendo que dessa imagem da infância de Kafka apresentada por Benjamin, se conforma um interstício espaço-temporal, o qual situa a existência do momento como evento, ou acontecimento; enquanto em sua materialidade bidimensional a imagem fotográfica expõe uma parcialidade sugestionável como

2 Derivado de um ensaio inacabado que Benjamin havia escrito sobre Kafka, Uma imagem infantil, em homenagem ao décimo aniversário de sua morte, o trecho acima compõe a publicação "Sobre a fotografia" a qual reúne textos em que o crítico pensa a fotografia historicamente (BENJAMIN, 2013). 
sentido de representação do real por certa invisibilidade, o que exige a atuação do sujeito para inferir-lhe referências e atribuir-lhe significados.

Nessa narrativa benjaminiana da fotografia de Kafka, subjaz à percepção fugaz de algo que poderia ter sido em um passado distante, um futuro que avança sob a perspectiva de quem olha o passado a partir do presente, problematiza o real visto na imagem fotográfica e o interpreta à luz de sua experiência. Pois, "a verdadeira imagem do passado perpassa veloz. O passado só se deixa fixar, como imagem que relampeja irreversivelmente, no momento em que é reconhecido" (BENJAMIN, 1986, p. 224). O reconhecido na fotografia está implicado pela consciência de uma emanação que este sujeito que a observa, o receptor da imagem, detém com referências ao passado acionado por um vivido contido de significados. Diante disso, parece plausível que a cada novo olhar sobre uma fotografia, sua interpretação conduza a uma nova construção desse passado o que restitui seu receptor de experiência.

Para Benjamin (1986), nessa atitude de voltar-se ao acontecimento a fim de compreendê-lo e interpretá-lo, não se trata apenas de conhecer o passado "como ele de fato foi" (BENJAMIN, 1986, p. 224). Mas, posto que na memória as impressões da realidade se misturam, compreender e interpretar o passado pela imagem e ao que ela remete, implica se apropriar de uma reminiscência que leva o sujeito a rememorar o vivido, do qual não pode dissociar as interpretações que lhe foram agregadas no decurso do processo histórico, à sua ressignificação.

Deste modo, aludo ao exercício de como pensar a partir da fotografia, a compreensão do momento em questão, o qual parece estar contido na imagem, enquanto interstício espaço-temporal. $\mathrm{E}$, sendo este momento capturado pela fotografia, uma representação do contexto educativo entendida como acontecimento, é que seus elementos podem ser percebidos enquanto manifestações culturais que referem a prática educativa evidenciada na imagem, cuja reflexão se revela em experiência.

Sob o viés da perspectiva benjaminiana de escovar a história a contrapelo (BENJAMIN, 1986) a fim de enxergar o que se esconde por debaixo e entre os fatos que demarcam trajetórias no processo histórico, se subentende a revelação de uma inflexão histórica (BENJAMIN, 2012). Tal qual o efeito produzido por uma luz lançada do presente sobre o passado encontra o acontecimento e lhe atravessa seus vazios como sementes preciosas do tempo (BENJAMIN, 1986), invisíveis na imagem fotográfica, mas que urgem de significados a serem construídos por quem as interpretam, nesse encontro de horizontes.

Tal como refere a lacuna arendtiana, a luz do presente invade o espaço intemporal por caminhos impressos e fugazes, em que o pensamento ocupa a atmosfera do lugar representado na imagem, preenche frestas, produz sombras, abre possibilidades na amplidão pela difusão do pensar concretizado como refle- 
xão, indicando trajetórias plausíveis. Nos percursos desses caminhos, indícios do real podem ser detectados, como pistas daquilo que não se vê na imagem, mas dão a pensar.

A questão não é que realidade é melhor, que vontade está no melhor caminho, senão: que realidade faz convergência interior com a verdade?; que verdade se prepara interiormente para convergir com o real? Somente aquele que dê aqui uma resposta clara é 'objetivo'. Porém, não frente aos seus contemporâneos (na realidade não se trata disso), senão frente aos acontecimentos (considerando que isso é o decisivo). Somente aquele que no seio da decisão faz uma paz dialética com o mundo pode captar o concreto. Mas quem queira decidir-se a partir 'da base dos fatos' verá como os fatos lhe dão as costas. (BENJAMIN, 2012, p. 22)

Se entendermos o concreto a que Benjamin se refere como o real conformado em acontecimento, por visíveis e invisíveis, a revelação do que subsiste em um evento do passado parece depender dessa iluminação materializada pelo pensamento. Em sua evidência os fatos se compõem como referências sobre a realidade, mas, sendo essas entremeadas, ao serem iluminadas pelo presente produzem sombras, aspectos não visíveis que somente poderão ser delineados pelas contraposições da reflexão dialética, cujas consequências podem revelar invisíveis. À análise do vivido enquanto acontecimento ressignificado no processo histórico, e cuja revelação decorrente da reflexão permite enxergar frestas ou espaços vazios, se suscita que o sujeito do presente lhe faça perguntas à sua compreensão e interpretação. Sob essa perspectiva é que a crítica benjaminiana contribui com o ato de pensar a prática educativa pela experiência, por situar o olhar sobre o visível na imagem fotográfica contida de vestígios do vivido, iluminado e confrontado com este presente que ora se volta ao passado, pelo qual se pode vislumbrar invisíveis na imagem.

Referindo-se à natureza da imagem fotográfica, em Pequena história da fotografia, Benjamin (1986) denota que o observador da imagem busca o imperceptível na centelha do acaso desse presente capturado pelo mecanismo fotográfico, daquilo que escapa ao olhar do fotógrafo e pode ser descoberto em reiteradas tentativas de olhar para trás, retrocedendo o movimento que a própria imagem projeta.

A natureza que fala à câmara não é a mesma que fala ao olhar; é outra, especialmente porque substitui a um espaço trabalhado conscientemente 
pelo homem, um espaço que ele percorre inconscientemente. (BENJAMIN, 1986, p. 94)

Há um inconsciente ótico (BENJAMIN, 1986) que a fotografia sugere em sua revelação, não perceptível na materialidade impressa pela configuração de seus elementos, mas naquilo que podemos depreender dela, quando entrevemos um movimento contido dada a ausência da exatidão de sua execução, por aquilo que dá a pensar. Como supõe o gesto no ato de escrever, o olhar em um retrato, a posição das árvores sujeitas ao vento em uma paisagem. A fotografia não captura o movimento em si, como o cinema o faz, mas a sugestão da ação, não concluída e sim prenunciada, que impinge a sua paralisação como sentido fotográfico, de um tempo que para a ação. Imobilizado o tempo na imagem, se produz o vazio. Um vazio provocado pelo rompimento do tempo, pela estagnação do movimento, que resulta a configuração de elementos e conforma a imagem de referentes visíveis e de invisíveis. O que existe de concreto nesse vazio são seus referentes, ou seja, aquilo que está materializado pela imagem, enquanto os invisíveis decorrem da sugestão de uma presença, que seus referentes enunciam e apenas a interpretação poderá nutrir de significados.

Nesse ínterim, a fotografia é uma forma concreta de evidenciar o vivido por uma materialidade vazia, o que enseja o exercício de pensar a experiência a partir do que se vê na imagem e de transcendê-la a fim de atribuir-lhe significados.

Ainda, posto que à interpretação da fotografia se lhe adere o caráter de verossimilhança, como representação do real por esse efeito de uma tecnologia que fixa elementos da realidade; enquanto parte de um todo, enxergar para além do que a imagem evidencia supõe o estabelecimento de relações, tendo em conta as propriedades características da técnica e a capacidade interpretativa dos sujeitos que a observam.

Desta forma, o estudo sobre a Estética da Recepção implicada pela participação (VÁZQUEZ, 2005), mostra-se pertinente para este método de pesquisa por indicar uma perspectiva à interpretação da imagem fotográfica que permite reflexionar o que se vê em uma fotografia para além das evidências, mediante o exercício ativo do receptor da imagem por seu pensamento crítico. Nisso reside o estabelecimento de relações que o receptor da imagem é capaz de realizar entre os elementos visíveis na fotografia com algo que conhece. Dado que o efeito fotográfico de corte do tempo ou sua paralisação, gera um hiato que busca seu complemento, a concretização do acontecimento no ato de pensar a experiência.

A fotografia, portanto, contém indícios de uma dada realidade que podem ser investigados pelo observador, como oportunidade à reflexão da experiência educativa. 


\section{A fotografia sob a dimensão estética à sua constituição como objeto da cultura: olhar fotográfico e recepção da imagem}

A premissa de que enxergamos em uma fotografia indícios de uma dada realidade, cuja observação gera perguntas ao passado e revela matizes à sua interpretação no encontro de horizontes, se correlaciona ao ato de pensar a experiência enquanto oportunidade de ressignificar o vivido pela perspectiva do presente.

Essa ideia transcende o conceito da fotografia como mera reprodução da realidade, espelho do real, senão, aspecto que nos remete a ela, seja pelo próprio olhar, ou o olhar de outro, que cristalizou um momento do tempo vivido em imagem. Ainda que, na interpretação de qualquer fotografia, se instale o arraigado preceito de impressão do real dado pela representação visual de elementos visíveis de um determinado momento, o que condiciona o observador a atribuir um sentido de verdade ao que, só aparentemente a imagem enuncia. Com essa característica de verossimilhança, a fotografia se constitui objeto da cultura por relações que contribuem à construção de um campo do saber acerca do olhar, seja daquele que fotografa dada realidade, seja de quem observa fotografias e as interpreta, os quais partem de seus referentes e de certo modo os traduzem como representação.

Em Ensaios sobre fotografia, Sontag (1981) apresenta significados à trajetória da fotografia sob temas diferenciados dos quais, $\mathrm{O}$ mundo como imagens, permite relacionar elementos de uma estética a esse novo modo de ver que a fotografia instaurou. Acerca da realidade representada na imagem, a autora enfatiza a autoridade da fotografia em relação às demais imagens como formas de interpretação, sendo que à fotografia tal autoridade se tornou irrefutável diante dos efeitos característicos oriundos da técnica.

Essas imagens são verdadeiramente capazes de usurpar a realidade porque, antes de mais nada, uma fotografia é não só uma imagem (como o é uma pintura), uma interpretação do real - mas também um vestígio, diretamente calcado sobre o real, como uma pegada ou uma máscara fúnebre. (SONTAG, 1981, p.148)

Sendo vestígio, rastro, marca do real, daquilo que foi e subsiste como máscara fúnebre, a fotografia nos remete a ele por algo que nos faz lembrá-lo. $\mathrm{O}$ conhecido ou reconhecido relampeja e atesta o que vemos na imagem como 
uma existência, aludindo à ideia de verdade, no entanto, a imagem em si é mera aparência, não reproduz a realidade em sua totalidade, senão, uma perspectiva sobre ela, então, verossimilhança.

Esse atributo de verossimilhança presente na fotografia sugere o duplo sentido à interpretação de sua natureza, pois ao mesmo tempo em que deriva do real, como representação constitui uma escolha de um sujeito que a produziu, resultando em criação.

Em seus estudos sobre a natureza da fotografia como objeto da cultura de massas que, eventualmente, alcança estatuto de obra de arte, Felici (2011) delineia à acepção da fotografia como espelho 'do real', o desenvolvimento das artes. Deriva dessa relação uma ideia de que a imagem fotográfica é considerada como meio de expressão que se constitui em representação verossímil da realidade por ser uma criação originada do real e desse modo ganha credibilidade de documento.

Segundo Felici (2011), a concepção da fotografia como uma representação do real subsiste nos dias atuais por se constituir em uma prática socialmente incorporada, uma vez que,

a fotografia é percebida por um grande público (que massivamente faz um uso testemunhal da fotografia, graças às câmaras digitais de bolso, antes as câmaras "pocket" e "reflex", ou universais - de $35 \mathrm{~mm}$-, etc) como uma espécie de prova que certifica o acontecido no passado, na história pessoal e cotidiana de todos nós. (FELICI, 2011, p. 57).

Apesar do reconhecimento dessa relação automática da imagem fotográfica com o conceito do realismo, presente no senso comum, Felici (2011) enleva estudos acerca de uma ontologia da fotografia, em que propostas teóricas de diferentes autores desconstroem o sentido da fotografia como mera representação do real, ou, documento factual.

Constata-se no decurso da história da imagem, o quanto esse caráter documental, ora intrínseco à fotografia e apropriado pelo cinema evidencia seu poder de persuasão, haja vista sua utilização por Mussolini e Hitler, e no caso do Brasil, Getúlio Vargas (VIEIRA, 1998). Tal como demonstrou a história, o carisma e a ideia de invencibilidade veiculados por imagens desses ditadores e estadistas cumpriu seu papel ao disseminá-las como verdades. A respeito da produção fotográfica como instrumento de criação de uma imagem idealizada, se situa o trabalho realizado pelo fotógrafo oficial de Hitler, Heinrich Hoffmann, cuja amizade e confiança lhe possibilitou fotografar o Führer em todo tipo de 
poses, "assim pôde estudar seus movimentos e seus gestos para reter os mais vantajosos e usá-los durante seus discursos" (FREUND, 2014, p. 112).

Para Felici (2011), o problema à consideração da fotografia como documento se verifica na repercussão da fotografia de imprensa ou fotojornalismo em relação à percepção de mundo pela massa social, em que se pese a incorporação da qualidade de autenticação da fotografia aos fatos que o texto informa.

Diante da autenticação que a fotografia confere a um acontecimento, pois é fato que o que se pode ver na fotografia realmente existiu, estava lá (BARTHES, 1980), frente a sua interpretação sobrevém o sentido de verossimilhança transcendendo a inegável aparência dos elementos que compõem a imagem, pelas inúmeras possibilidades interpretativas conforme se multiplicam seus observadores. Com isso, se confirma a reconhecida polissemia da fotografia (MARTINS, 2013) que coloca em questão seu caráter de prova de dada realidade, pela multiplicidade de sentidos que ela sugere, em possibilidades interpretativas decorrentes das relações entre imaginário e imagem fotográfica, como seus matizes.

Mediante estudos realizados com a análise de fotografias sob diferentes propósitos, Martins (2013) destaca que, "o leitor da fotografia pratica um confisco visual da imagem, remontando-a, a partir de suas insuficiências, no seu próprio código de leitura que é também o manual sintético de suas experiências e das experiências do seu ver." (MARTINS, 2013, p. 46). Para esse autor, ler uma fotografia significa decifrá-la a partir da própria experiência, dada a insuficiência que a imagem capturada em uma fração de segundo impõe ao paralisar o momento. Tal como afirma o estatuto da estética da recepção implicada pela participação do sujeito (VÁZQUEZ, 2005), que relaciona a obra de arte à sua experiência, acerca da observação da imagem fotográfica se pressupõe que esta aciona em cada observador uma busca pelo conhecido, o qual se serve da gama de significados oriundos de suas próprias referências sobre o tema que a imagem aborda ou que provoca a pensar para além dele.

Se a evidência dos fatos se materializa por algo concreto que remete ao real visível na imagem fotográfica, enquanto técnica de impressão da luz, pode-se afirmar que os elementos aparentes em uma fotografia são visíveis nos limites de sua natureza bidimensional sob as condições que a câmara impôs. Isto é, toda fotografia se constitui por efeitos do tempo de exposição, que relacionam a abertura do obturador e a velocidade com que a luz foi capturada, resultando em uma impressão dessa realidade. Mas, ainda que sujeita aos recursos mecânicos ou eletrônicos que determinam seus efeitos, não se pode negar que toda imagem que resulta a fotografia é delimitada a partir de uma visão sobre a realidade - do olho que vê ou de uma perspectiva - e materializada pela decisão do instante a ser 
capturado. Portanto, uma escolha, dentre tantas possibilidades acerca do que foi testemunhado pelo sujeito fotógrafo, o que denota certo relativismo à fotografia.

Diante disso é que se depreende o entendimento de que toda fotografia expressa um ato de criação, sob a escolha de um sujeito em um instante dos tempos (KOSSOY, 1989). Ainda que, como ato de criação toda fotografia corresponda a uma produção, tal aspecto não retira o caráter documental da fotografia, dado pelas coordenadas de tempo e espaço que situam o fotógrafo. Esse sujeito, inserido em uma sociedade, com uma determinada experiência e enredado de certa contemporaneidade, captura em uma fração de segundo a versão da realidade sob sua perspectiva de mundo, a qual enfatiza, seja pelo ângulo que elege, ou pelos efeitos que a imagem produz em função da composição dos elementos físicos que a resultam, transmitindo uma mensagem.

O registro visual documenta, por outro lado, a própria atitude do fotógrafo diante da realidade; seu estado de espírito e sua ideologia acabam transparecendo em suas imagens, particularmente naquelas que realiza para si mesmo enquanto forma de expressão pessoal. (KOSSOY, 1989, p. 27)

À luz do que destaca Kossoy (1989), visto que o fotógrafo é um sujeito implicado em um tempo e um espaço, sua ideologia, entendida sob o aporte cultural que se lhe agrega no decurso de sua experiência de vida, exercerá influência na perspectiva sobre o que fotografa. Dito isso, parece pertinente pensar as relações entre os elementos presentes no aspecto escolhido e a visão de mundo do sujeito que os elegeu. O que constitui a visão de mundo do sujeito marca de recorrências a sua obra fotográfica, tal como destaca Martins (2013), acerca do protagonismo dos fotógrafos Martin Chambí e Sebastião Salgado frente aos seus trabalhos de cunho documental, fortemente marcados por suas ideologias, evidenciadas pelos temas ou pela estética em sua forma.

Desse ponto de vista documental, histórico, é que se pode afirmar que toda fotografia guarda elementos de uma dada realidade, capturada por um sujeito situado nesse espaço-tempo em que está inserido. Marcadamente, sob a influência da relação entre os tempos da história da sociedade e da própria vida do sujeito fotógrafo como mundos que seu olhar contém.

De um ponto de vista semiótico, estético, a fotografia como produção bidimensional que conjuga composição, contraste e textura, se configura por um sistema sígnico particular. O olhar fotográfico se constrói, implicado por significações que dizem respeito ao que o sujeito que fotografa detém no momento dessa captura como algo que o afeta por uma observação imediata 
(BENJAMIN, 1986), o que nem sempre é previsto mas que de algum modo é perceptível por sua sensibilidade.

Portanto, se mostra pertinente pensar que as referências do olhar fotográfico se fundam por preceitos de determinação histórica e dimensão estética. E, uma vez que esse sujeito que fotografa está imerso em uma realidade sociocultural, movido por sua forma de ver, atuar e se expressar, ao realizar sua escolha e traduzi-la em uma imagem, produz um objeto que será apropriado culturalmente ao ser socializado.

Como objeto da cultura é que a fotografia se constitui em instrumento, um aparato de observação cuja forma material de natureza bidimensional, plana, impressa ou digital, permite a difusão de um aspecto da realidade capturado pela escolha do olhar fotográfico e que pode ser apreciado, inúmeras vezes, por meio da recepção da imagem, resultando em múltiplas interpretações.

De mera associação de referências à complexidade de relações sobre aquilo que se vê em uma fotografia, "seja o que for que ela dê a ver e qualquer que seja a sua maneira, uma foto é sempre invisível: não é ela que nós vemos" (BARTHES, 1980, p. 20). O invisível, um algo que não se pode ver, remete a esse vazio que urge ser preenchido com referentes a partir do que sua composição aciona no observador. Da perspectiva do observador da imagem, o seu receptor, podemos pensar que o significado de uma fotografia está sempre atrelado a algo externo a ela.

Isso reitera a definição da fotografia como representação, ou seja, ela contém indícios de uma realidade, no entanto, não transmite uma mensagem codificada por signos, ao contrário, o que se enxerga na fotografia a partir dos significados que são atribuídos aos elementos perceptíveis nela é que constituem uma mensagem. Para Barthes (1980), a fotografia em si não poderia ser entendida como linguagem, uma vez que esta se estrutura por signos, os quais exigem um sinal, dado que o que se vê na fotografia não pode ser classificado como sinal, mas um aspecto do real capturado em um único e irrepetível instante.

Sobre a natureza da imagem fotográfica, e em acordo com Barthes (1980), Philippe Dubois (1994) propõe compreendê-la a partir de seus referentes os quais entende como índice, com o que também permite problematizar a conotação dada à fotografia enquanto mera representação do real imputada pelo realismo. Segundo esse autor, há uma pragmática irredutível na qual a referencialização da fotografia se inscreve, pois que se torna inseparável de sua experiência referencial, ou seja, do ato que a cria. O que se pode depreender como um momento único, singular, intrínseco à relação entre o produtor da imagem e ela própria.

Referindo-se à perspectiva da fotografia no âmbito dos signos indiciais como um traço que resulta do ato fotográfico, Felici (2011) delineia um sentido que contribuiu para o entendimento da fotografia em sua materialidade. 
Se o signo fotográfico mantém com seu referente uma relação de conexão física, esta conexão é a distância, uma distância tanto espacial quanto temporal. A fotografia dá do objeto uma visão estritamente plana e sem relevo. O traço fotográfico é, finalmente, luminoso e sua estrutura descontínua, uma vez que a fotografia é um composto de uma infinidade de grãos ou pontos de tamanhos distintos, o que determina sua resolução. A luz determina a configuração da imagem fotográfica (etimologicamente, "escrita com luz"), enquanto que a descontinuidade, mais do que estrutural (granular) é, sobretudo temporal na medida em que a fotografia supõe um corte, uma seleção, do contínuo temporal. (FELICI, 2011, p. 63).

Essa descrição material da fotografia permite aludir ao que caracterizaria a peculiaridade do referente na imagem fotográfica, segundo sua natureza física, e sugere que aquilo que o olho vê e captura é transformado pelos efeitos de uma tecnologia, cujo resultado é a materialidade fotográfica.

Do ponto de vista da temporalidade instantânea, aparentemente efêmera, a captura de uma fração de segundo apresenta em sua materialidade impressa na imagem fotográfica um instante do tempo contido, congelado, como algo singular que se refere ao todo visível e que de certo modo o detém. "A fotografia não retrata apenas determinado tema, é também uma homenagem a ele. É parte do tema e um prolongamento dele; como também um meio potente de controlá-lo." (SONTAG, 1981, p. 149). A ideia de homenagem consiste em que, ao eleger determinada abordagem sobre o tema, o sujeito fotógrafo evidencia esse recorte da realidade para eternizar pela imagem, o qual se compõe no imaginário como sendo parte do próprio tema, e isso consiste em uma forma de controle tal como sugere Sontag (1981).

Remetendo-se às primeiras décadas do século $\mathrm{XX}$, quando a fotografia se emancipou dos estúdios fotográficos e se fortaleceu como abordagem jornalística, Sontag (1981) destaca esse modo do homem moderno capturar e se apropriar de tudo que vê por meio dessa tecnologia que, segundo a autora pareceu cumprir a promessa de democratizar todas as experiências traduzindo-as em imagens. Dada a sensação de que diante de uma fotografia podia-se acessar o mundo.

Acerca dessa perspectiva, a captura da imagem define a forma e a função do fotógrafo enquanto autor de fotografias, como um produtor de versões sobre a realidade. Deste modo, sem pretender nominar a subjetividade do sujeito que fotografa, interessa a este método de pesquisa, a captura, ou seja, os referentes que a percepção do observador detém na emanação desse testemunho do fotógrafo composto em imagem.

Ao partir do que a imagem detém, enquanto captura da realidade, decorrem relações entre aquilo que se vê na fotografia e o que não se vê, o que a 
experiência dá a pensar, como matizes de interpretações. Da compreensão de que a fotografia materializa referentes, como indícios da relação entre o mundo do sujeito que fotografa e um aspecto do mundo da realidade que o mobiliza, mediante o diálogo entre essa materialidade com outros mundos tantos quantos sejam seus observadores, é que resultam novas possibilidades interpretativas aos seus referentes.

A partir dessa dialogia denoto que enquanto objeto da cultura, a fotografia comunica mensagens dessa relação que seu observador estabelece com os elementos nela cristalizados. Aqui reside a importância desse aspecto que marca a fotografia como constructo de infinitas possibilidades interpretativas, o fato de que possa levar o observador da imagem a rememorar suas experiências e atribuir significados aos referentes que ela contém. Seja do ponto de vista de quem cria e produz a imagem fotográfica ou do ponto de vista de quem a detém e a observa, dar visibilidade à fotografia é o que a torna um objeto da cultura; enquanto que, sendo manipulável por diferentes perspectivas, sob diferentes suportes - impresso ou digital - é que ela se torna aparato de observação.

Mediante as possibilidades que a fotografia enseja como aparato de observação para analisar o cotidiano educativo, de provocar o olhar do observador à compreensão de suas relações, além da evidência dos elementos que compõem e estão cristalizados na imagem, sua investigação permite perscrutar o contexto ora visitado, rememorar a vivência de estar ali e recuperar outros aspectos concernentes às concepções que delineiam a prática educativa vislumbrada.

Ao utilizar a fotografia enquanto aparato de observação, para além de possibilitar a caracterização de aspectos da prática educativa pelos elementos materiais ora evidenciados na imagem, se propõe o exercício de pensar as inúmeras relações que os sujeitos estabelecem com essa materialidade e entre si. E as relações possíveis a serem pensadas dos sujeitos entre si, adultos e crianças, decorrem da análise propiciada pela compreensão e enredamento de determinantes culturais e sociais vinculados ao contexto em estudo, haja vista as evidências impressas como vestígios de sua presença no cotidiano, cristalizados na imagem fotográfica.

O simulacro que visualizo dessa dinâmica impressa por vestígios do cotidiano educativo, inspira-se no pressuposto da lacuna arendtiana como uma colisão de forças entre passado e futuro (ARENDT, 2013). De um lado o adulto, esse sujeito representante da tradição, que a apresenta por meio de sua prática e configura o contexto com sua intervenção como um modo de organização; de outro lado a criança, esse sujeito novo no mundo a qual, por desconhecer parte do que vê, interage com o que lhe é apresentado trazendo em sua perspectiva a novidade, com o que modifica e também interfere nesse contexto mediante sua participação. 
Provocada pelo pressuposto arendtiano e diante dos elementos evidentes nos contextos investigados me pergunto: como se conjugam a tradição, enquanto esse legado cultural que imprime na criança o sentido de pertencer a um grupo, e a novidade, constituinte da própria criança em sua forma de se expressar no mundo, em cada momento representado?

O contexto educativo, marcado pela dinâmica e interações que propicia, entendido como lugar onde as relações se constituem também pela configuração de seus elementos, sugere uma abordagem que interpreta a sua conformação por mundos em relação. Nesse sentido, a percepção dos elementos do contexto se movimentam no pensamento pela possibilidade de transcendência que o inconsciente ótico (BENJAMIN, 1986) implica a configuração visível na imagem fotográfica, e se conecta à experiência pela sensação de verossimilhança, com o que se pode delinear uma nova perspectiva para pensar a prática educativa.

Dito de outro modo, ao delimitar a fotografia como aparato de observação, este método de pesquisa almeja relacionar os elementos que compõem a imagem, referentes de uma prática educativa e indícios do vivido, à gama de possibilidades que o pensamento dá a pensar.

Nessa perspectiva, a dimensão estética constitui o âmbito em que o olhar fotográfico e a visão de seu receptor conformam pontos de vistas inter-relacionados à interpretação dos saberes implicados na experiência educativa, ressignificada pela compreensão. Ao interpretar o que se vê na imagem enquanto indício da prática educativa, aquilo que o observador aciona da experiência educativa constitui o próprio pensar sobre o educativo na prática evidenciada. Para isto, depende iluminar a trama de relações educativas e revelar seus invisíveis como aspectos que constituem saberes da experiência educativa.

Sob essa perspectiva, concordando com Barthes (1980) e Gadamer (2013), conceituo a fotografia como objeto da cultura que expressa uma visão sobre a realidade e se constitui em aparato de observação pela possibilidade de gerar interpretações decorrentes daquilo que afeta o sujeito receptor da imagem. De um lado, enquanto interstício espaço-temporal, a fotografia conflui referentes de determinada situação do real capturados na observação imediata (BENJAMIN, 1986) pelo sujeito fotógrafo que conforma uma complexidade singular na estética do seu olhar. Por outro lado, se voltar ao contexto educativo por meio da fotografia enquanto aparato de observação, se constitui em um exercício de ampliação da experiência estética mediante o olhar do outro e de compreensão dessa realidade pelo que os referentes da prática educativa e das relações que estes sugerem dão a pensar (VIEIRA, 2016). 


\section{Considerações sobre o método}

A fotografia tem sido amplamente utilizada no âmbito da educação, se compondo a diferentes abordagens sobre documentação pedagógica, como recurso metodológico e instrumento de investigação, para representar o vivido, evidenciar concepções, demarcar fatos do processo educativo. Enfim, sua apropriação é diversa e por vezes suscita reflexão sobre os modos de utilização, para que não se banalize os efeitos de sua recepção.

$\mathrm{O}$ aprofundamento que este método propõe como possibilidade à fotografia e sua relação com a experiência educativa, qualifica a produção de análises à compreensão que essa relação enseja. Sustentado pela premissa de que a fotografia visibiliza indícios de uma dada realidade, imprimindo-lhe caráter de verossimilhança, tal método consiste na problematização da imagem pelo pensamento crítico reflexivo do seu receptor, que busca invisíveis na observação de seus referentes gerando perguntas ao passado e revelando matizes à sua interpretação pelo encontro de horizontes. A isso denomina o ato de pensar a experiência educativa tendo a fotografia como aparato de observação, uma oportunidade de ressignificar o vivido pela perspectiva do presente.

Portanto, interpretar uma fotografia não se resume em um ato objetivo sobre os referentes que evidencia, mas, depende de entendê-la na confluência de seus índices, mundos em relação. Sob uma perspectiva histórica e estética, o sujeito que captura dada realidade está implicado por um modo de vê-la ao cristalizá-la como fotografia, enquanto o sujeito receptor da imagem fotográfica é capturado por indícios de seus invisíveis ao pensar a experiência educativa, exercício do pensamento pedagógico.

\section{REFERÊNCIAS}

ARENDT, H. Entre o passado e o futuro. 7. ed. São Paulo: Perspectiva, 2013.

BARTHES, R. A câmara clara. Arte e Comunicação, Lisboa: Ed. 70, 1980.

BENJAMIN, W. Magia e técnica, arte e política. 2. ed. São Paulo: Brasiliense, 1986.

BENJAMIN, W. Imágenes que piensan. Madrid, Espanha: Abada, 2012.

BENJAMIN, W. Sobre la fotografia. 5. ed. Valencia: Pre-textos, 2013. 
CONTRERAS, J. D.; PÉREZ, N. de L. F. (Comps.). Investigar la experiencia educativa. Madrid: Ediciones Morata, 2010.

DUBOIS, P. O ato fotográfico. São Paulo: Papirus, 1994.

FELICI, J. M. Cómo se lee una fotografía: interpretaciones de la mirada. 4. ed. Madrid: Ediciones Cátedra, 2011.

GADAMER, H. G. Hermenéutica, estética e história. 2. ed. Salamanca, Espanha: Ediciones Sígueme, 2013.

FREUND, G. La fotografia como documento social. Barcelona: GGilli, 2014.

KOSSOY, B. Fotografia e história. São Paulo: Ática, 1989.

MARTINS, J. S. Sociologia da fotografia e da imagem. 2. ed. São Paulo: Contexto, 2013.

SONTAG, S. Ensaios sobre fotografia. Rio de Janeiro: Arbor, 1981.

VÁZQUEZ, A. S. De la estética de la recepción a una estética de la participación. México: UNAM, 2005.

VIEIRA, D. M. João Batista Groff, um olhar fotográfico no Paraná das primeiras décadas do século XX. Curitiba: UFPR, 1998.

VIEIRA, D. M. A constituição do eu e o espaço pedagógico na educação infantil: formação para a docência. Curitiba, 2011. Disponível em: <http://educere.bruc.com.br/ CD2011/pdf/4538_3347.pdf>. Acesso em: 26 out. 2015.

VIEIRA, D. M. Imagens da experiência educativa de professores da educação infantil no espaço-ambiente do Proinfância. 2016. 228 f. Tese (Doutorado em Educação) - Setor de Educação, Universidade Federal do Paraná, Curitiba, 2016.

Texto recebido em 27 de outubro de 2018. Texto aprovado em 30 de janeiro de 2019. 